\title{
IMPLEMENTASI SOFTWARE BERHITUNG BERBASIS ANDROID DI TAMAN KANAK-KANAK KECAMATAN JAGAKARSA
}

\author{
Naely Farkhatin \\ Program Studi Informatika, Universitas Indraprasta PGRI Jakarta \\ naely_farkhatin@yahoo.com
}

\begin{abstract}
Abstrak
Pengembangan Teknologi Informasi pada prinsipnya membantu manusia dalam berinteraksi antar sesama dan dengan objek-objek di sekitarnya. Perubahan teknologi yang terjadi membuat sistem komunikasi dan komputer menjadi lebih mudah, kolaboratif, serta transparan terhadap pemakainya, adalah salah satu keterampilan penting yang dibutuhkan anak-anak dalam pembelajaran. Berbagai metode belajar berhitung pada pendidikan di Taman Kanak-kanak. Kemampuan berhitungpun bermunculan untuk membantu para guru dan orang tua mengajarkan keterampilan ini. Akan tetapi, metode saja sebetulnya tidak cukup tanpa adanya aplikasi system yang digunakaan dalam membantu pembelajaran, karena setiap anak itu unik, dan keunikan itu membutuhkan cara pembelajaran yang berbeda-beda. Yang lebih menentukan adalah pemahaman orang tua tentang bagaimana sebetulnya anak-anak itu belajar dan cara pembelajarannya. Berdasarkan uraian di atas maka penting dibuat sebuah media pembelajaran berupa aplikasi yang dapat menarik dan mempermudah proses belajar anak dengan konsep belajar sambil bermain yang dapat dilakukan di luar waktu belajar formal. Media ini dapat digunakan dengan fleksibel. Dalam penelitian ini kami melakukan penerapan software berhitung Berbasis Android di taman Kanak-kanak Kecamatan Jagakarsa.
\end{abstract}

Kata Kunci : Android; Teknologi Pembelajaran ;Berhitung; Taman Kanak-kanak

\begin{abstract}
In principle, the development of information technology helps people to interact with others or surroundings. Further, with the change in technology providing simpler, more collaborative and more transparent communication and computer system to many people, it is also important for children to have skill in computer that they can learn effectively. Counting skill has been introduced to kindergarten, creating various counting methods to help teachers and parents to teach it. However, the methods will not be effective without the use of application system in a learning process because every student is unique that he needs different way of learning. A more decisive matter is the parent's understanding about how the children learn and what their way of learning is. Based on the description above, it is necessary to provide a learning media in the form of application which can draw children's interest and facilitate children's learning process with a play-based learning concept applied beyond the formal learning time in which this media can be flexibly used. This research is conducted by applying android-based counting software at kindergarten in Jagakarsa.
\end{abstract}

Keywords : Android, Learning Technology, Counting, Kindergarten

\section{PENDAHULUAN}

\section{Latar belakang}

Perkembangan teknologi yang pesat sekarang ini berpengaruh terhadap proses pendidikan anak usia dini. Menurut teori piaget [1] mengatakan bahwa "usia 3-7 tahun termasuk dalam perkembangan kognitif tahapan praoperasional. Dikatakan praoperasional karena pada tahapan ini anak menggunakan kemampuan gambar simbolik dalam berpikir dan juga aktivitas bermain kreatif akan meningkatkan daya pikir anak". Bermain kreatif merupakan salah satu dari metode pembelajaran yang diterapkan bagi anak usia dini. Sedangkan saat ini kebanyakan pembelajaran lembaga TK masih menggunakan media buku panduan. Media tersebut menjadikan proses belajar mengajar menjadi terlalu serius dan juga monoton, sehingga 
menjadikan anak cepat bosan dalam mengikuti pelajaran. Kebanyakan anak pun menggunakan buku panduan saat mereka belajar pada waktu formal, padahal pendidikan anak dapat juga dilakukan di rumah maupun lingkungan sekitar pada setiap waktu. Sehingga hanya menggunakan buku panduan sebagai media pembelajaran untuk zaman sekarang saat teknologi sudah berkembang pesat sangat tidak fleksibel, praktis dan efektif dilihat dari buku panduan yang memiliki bobot yang berat dan besar sehingga susah dibawa kemana-mana.

Media adalah komponen sumber belajar atau wahana fisik yang mengandung materi instruksional di lingkungan peserta didik yang dapat merangsang peserta didik untuk belajar menurut [2] Kata media berasal dari bahasa latin medius yang secara harfiah berarti tengah, perantara, atau pengantar.

Pengelompokan berbagai jenis media apabila dilihat dari segi perkembangan dibagi kedalam dua kategori luas, yaitu pilihan media tradisonal dan pilihan media teknologi mutakhir [5]. Berdasarkan definisi di atas, maka dapat disimpulkan media adalah alat yang digunakan sebagai perantara dalam proses belajar mengajar, yang memudahkan guru untuk menyampaikan materi pembelajaran dan menarik minat peserta didik untuk belajar.

Dalam Undang-Undang Republik Indonesia Nomor 20 tahun 2003 tentang Sistem Pendidikan Nasional, dikemukakan bahwa pembelajaran adalah proses interaksi peserta didik dengan pendidik dan sumber belajar pada suatu lingkaran belajar. Setiap guru penting untuk memahami sistem pembelajaran. Karena dengan pemahaman sistem ini, setiap guru akan memahami tentang tujuan pembelajaran atau hasil yang diharapkan, proses kegiatan untuk mencapai tujuan yang ingin dicapai dan bagaimana mengetahui keberhasilan pencapaian tersebut.

Media pembelajaran didefinisikan sebagai alat-alat fisik dimana pesan-pesan instruksional dikomunikasikan [4]. Jadi seorang instruktur, buku cetak, pertunjukan film atau tape recorder dan lain-lain peralatan fisik yang mengkomunikasikan para instruksional dianggap sebagai media.

Berdasarkan uraian di atas maka penting dibuat sebuah media pembelajaran berupa software pembelajaran berhitung yang dapat melakukan dari mengenal angka(menggunakan keterangan bahasa inggris maupun bahasa Indonesia),sampai proses belajar berhitung. warna dan suara secara bersamaan yang dapat menarik ketertarikan anak dan dapat mempermudah proses belajar anak dengan konsep belajar sambil bermain yang dapat dilakukan saat diluar waktu belajar formal yang media ini dapat digunakan dengan fleksibel. Karena itu, penting dilakukan penelitian dengan judul "Penerapan Aplikasi Software Berhitung "SI KOMO" Berbasis Android di Taman Kanak-Kanak Jagakarsa.

\section{Tujuan penelitian}

1. Mengetahui hasil dari implementasi software berhitung diTaman kanakkanak kecamatan Jagakarsa

2. Mengetahui kelayakan software berhitung sebagai media pembelajaran untuk meningkatkan ketertarikan dan minat belajar anak dan meningkatkan potensi dalam diri berbasis Android.

3. Mengetahui tanggapan anak beserta orang tuannya terhadap penggunaan software berhitung berbasis Android sebagai media pembelajaran.

\section{Manfaat Penelitian}

Dari penelitian yang dilakukan, diharapkan dapat mempunyai manfaat sebagai berikut:

1. Bagi anak Anak dapat melakukan proses belajar baru dengan metode baru yaitu belajar berhitung berbasis andoid. Dengan 
penelitian ini diharapkan guru dan orang tua dapat menambah pengetahuan tentang media pembelajaran berbasis android dismartphone ini dapat dijadikan referensi sebagai media pembelajaran saat proses pembelajaran di PAUD, TK, rumah dan lingkungan.

2. Bagi peneliti

Bagi peneliti mendapatkan kesempatan langsung untuk menerapkan software belajar berhitung berbasis android sebagai media pembelajaran anak.

\section{METODE PENELITIAN}

\section{Tempat Penelitian}

Penelitian dilaksanakan di Taman KanakKanak daerah Jagakarsa, dimana kami memakai 3 sekolah sebagai tempat penelitiannya,yaitu (1. TK Fattahillah, 2.TK Assolihah dan TK Hanafi).

\section{MetodePenelitian}

Metode yang digunakan oleh peneliti adalah metode penelitian kombinasi.Tashakkori dan Creswell [3] memberikan definisi "Metode kombinasi adalah merupakan penelitian, dimana peneliti mengumpulkan dan menganalisis data, mengintegrasikan temuan dan menarik kesimpulan serta inferensial dengan menggunakan dua pendekatan atau metode kuantitaif dan kualitatif dalam satu studi". Disebut sebagai metode kuantitatif karena data penelitian berupa angka-angka dan analisis menggunakan statistic dan metode kualitatif karena data yang terkumpul dan analisisnya lebih bersifat kualitatif (mutu).

\section{MetodePengumpulan Data}

Teknik pengumpulan data yang digunakan untuk mendapatkan data mengenai respon anak terhadap penggunaan software berhitung menggunakan teknik kuesioner dan wawancara. Berdasarkan macammacam kuesioner dalam penelitian ini menggunakan kuesioner langsung dengan jawaban check list.

\section{HASIL DAN PEMBAHASAN Definisi Masalah dan Penyelesaian}

Teknologi informasi sangat berkembang cepat dalam satu decade ini. Kemajuan teknologi juga berkembang pada perangkat keras maupun perangkat lunak. Saat ini sudah banyak gadget atau perangkat teknologi mobile bermunculan.Dengan banyaknya teknologi mobile ini juga mendorong banyaknya aplikasi berbasis mobile menjamur.Sayangnya aplikasi pembelajaran berupa Software berhitung untuk Taman Kanak-kanak masih sangat sedikit, untuk ini peneliti berinisiatif untuk Membangun Aplikasi system belajar berhitung Berbasis Android yang diterapkan di Taman Kanak-kanak di Jagakarsa.

Dalam pendefinisian masalah dan penyelesaian penelitian melakukan berbagai analisis dan solusi penyelesaiannya, diantaranya yaitu

\section{Analisis Masalah Umum}

Masalah umum yang dihadapi adalah bagaimana membuat aplikasi/software sebagai media pembelajaran ini menarik dimata penggunaya itu anak-anak dengan target Taman kanak-kanak di Jagakarsa. Untuk itu penulis menggunakan unsur multimedia seperti gambar dan audio sebagai solusinya.

\section{Analisis Aplikasi Sejenis}

Peneliti melakukan observasi terhadap aplikasi sejenis yang sudah ada sebelumnya. Dengan melakukan analisis ini penulis mendapatkan ide untuk membangun aplikasi/software yang lebih baik.

\section{Analisis Materi Pembelajaran}

Dalam hal ini peneliti menganalisis materi apa saja yang akan disajikan dalam system aplikasi media pembelajaran ini, apakah materi yang disajikan bias menjadi panduan anak untuk Belajar berhitung dan mengenal angka dalam bentuk, suara, dan namanya menggunakan (bahasa inggris 
atau bahasa Indonesia) ? setelah menganalisis, peneliti mendapat kesimpulan bahwa materi yang di bawakan adalah materi dasar yang mengacu pada dasar berhitung dan pengenalan angka. Adapun materi pembelajaran yang di sajikan dalam system aplikasi media pembelajaran ini diantaranya adalah :

a. Mengenal Angka yang dimana terdapat jenis angka 0 sampai 10, didalamnya terdapat keterangan dari tiap-tiap angka yang menggunakan bahasa inggris maupun bahasa Indonesia.

b. Belajar berhitung, untuk poin belajar berhitung baik penambahan maupun pengurangan ini kita melakukan pembelajaran dimulai dari yang mudah sampai yang lumayan sulit

c. Latihan Soal / Quiz, Menu ini akan menguji seberapa besar pengetahuan anak terhadap materi yang sudah diajarkan,

4. Algoritma Penyelesaian Masalah dengan Flowchart dan Pseudocode

Aplikasi ini merupakan aplikasi pembelajaran berhitung berbasis Android yang diterapkan di Taman Kanak-kanak Jagakarsa di rancang dengan menggunakan flowchart dan psudocode. Flowchart digunakan untuk memetakan alur proses dari system sementara pseudocode untuk merancang logika program agar mudah di implementasikan. Berikut langkah - langkah yang di lakukan oleh penulis dalam menyelesaikan masalah dalam pembuatan system Aplikasi Belajar Berhitung "SI KOMO”.

Merancang Struktur Sistem Aplikasi

Belajar Berhitung "SI KOMO".

Membuat Flowchart

Membuat Pseudocode

\section{a. Pembahasan Algoritma}

Seperti yang sudah di bahas di bab sebelumnya aplikasi Belajarberhitung ini mempunyai Dua materi pembelajaran mengenalkan dan materi pembelajaran berhitung. Selain itu ada menu untuk bermain atau latihan soal yang akan mengukur sejauh mana anak dapat memahami materi yang sudah ada.

\section{Struktur Program Sistem Aplikasi Belajar Berhitung "SI KOMO"}

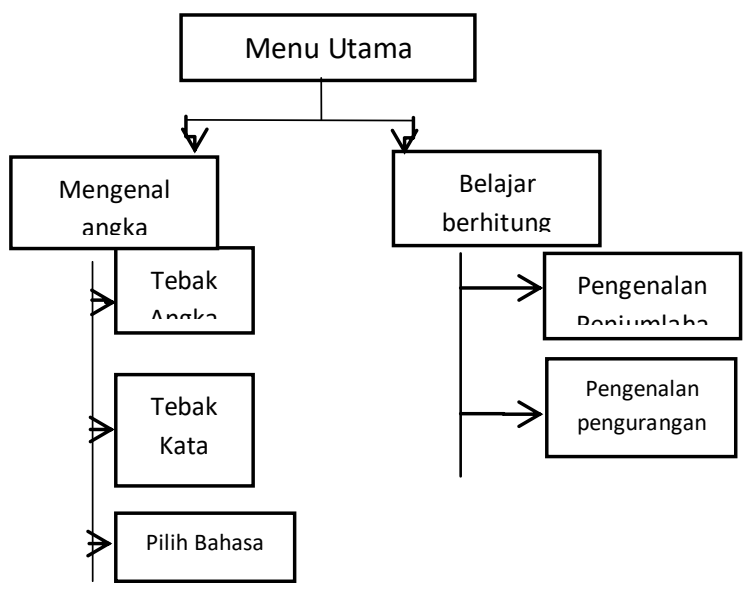

\section{Gambar 1. Struktur Program Belajar Berhitung "si komo"}

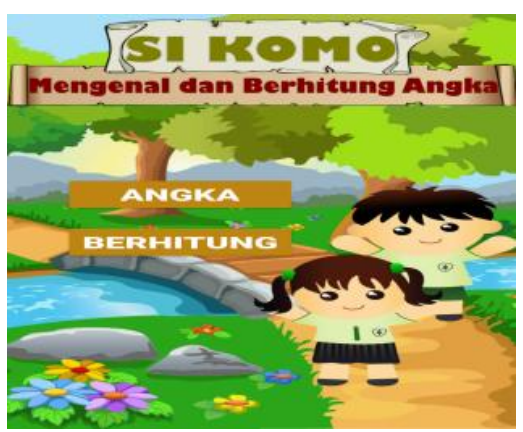

\section{Gambar 2 Menu Utama Belajar Berhitung "Si Komo"}




\section{Flowchart Menu Utama}

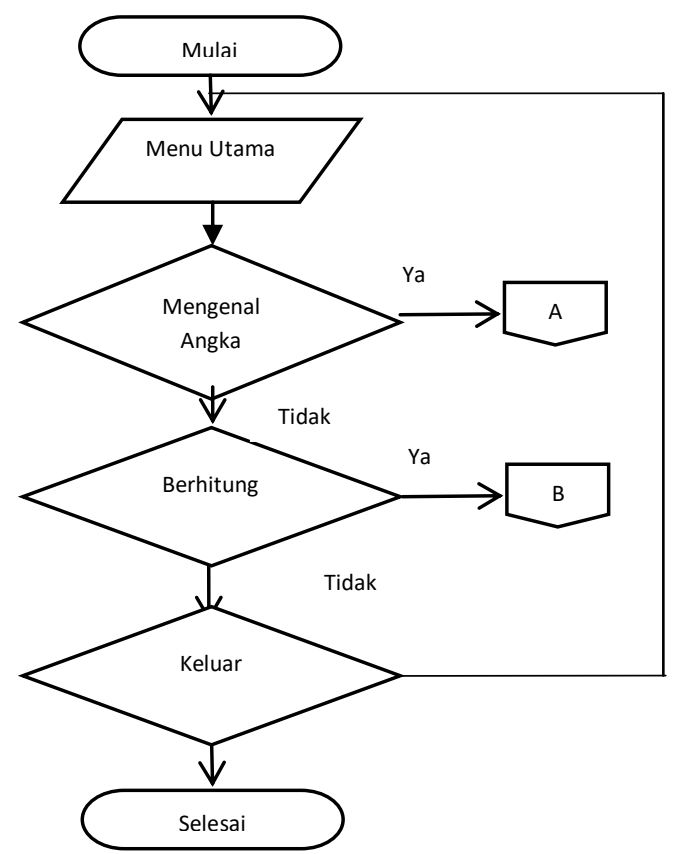

Gambar 3. Flowchart Menu Utama

Pada flowchart diatas pengguna di awal aplikasi di hadapkan beberapa pilihan menu, di antaranya Mengenal angka, dan Berhitung. Apabila pengguna memilih salah satu menu maka halaman lain akan muncul sesuai pilihan pengguna.

\section{Pseudocode}

Tampilkan Menu Utama

Do Pilihan

Pilih "Mengenal Angka" Lalu“ Tampilkan halaman Mengenal Angka"

Pilih = "Berhitung" Lalu" Tampilkan materi Belajar berhitung"

Pilih = "Kembali" Lalu "Keluar Aplikasi" End Do.

\section{Flowchart Mengenal Angka}

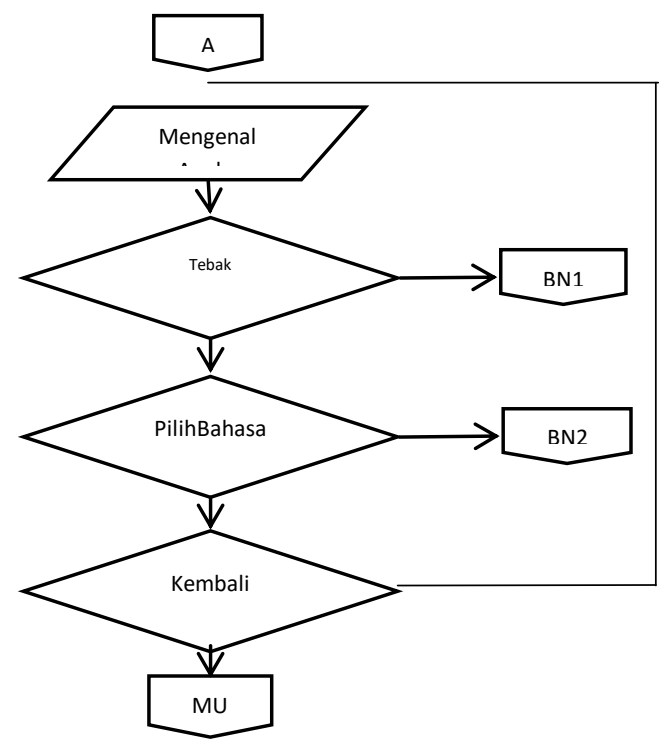

Gambar 4. Flowchart mengenal Angka

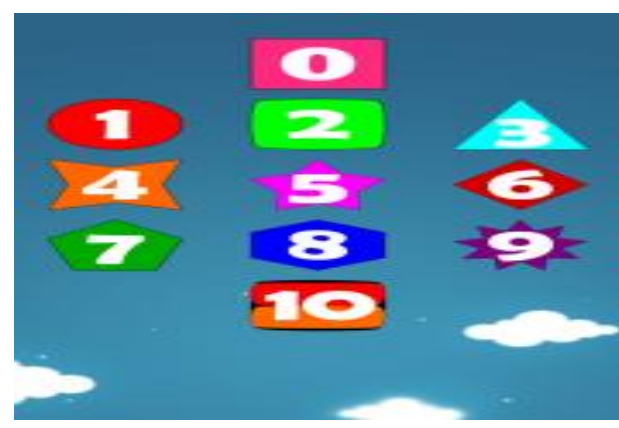

Gambar 5. Menu mengenal Angka

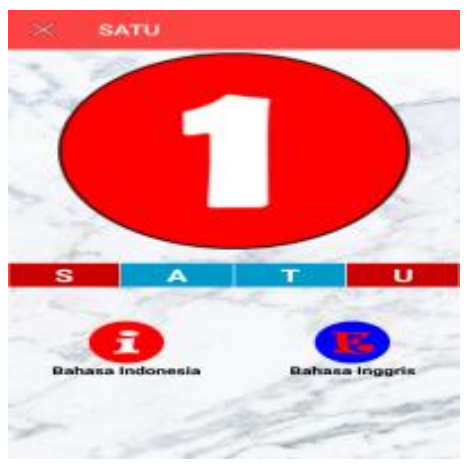

Gambar 6. Menu pilih bahasa

Halaman ini akan keluar jika pengguna memilih menu Mengenal Angka saat berada pada menu utama,dan pilihan 
bahasa Untuk keluar pengguna dapat menggunakan tombol back dari perangkat android yang akan kembali pada menu utama.

\section{Pseudocode}

Tampilkan Menu MengenalAngka

Do Pilihan

Pilih = "Tebak Angka" Lalu" Tampilkan quis Tebak Angka"

Pilih = "Pilih Bahasa" Lalu" Tampilkan

Pemilihan Bahasa"

Pilih = "Kembali" Lalu "Menuju Menu Utama"

End Do

\section{Flowchart berhitung}

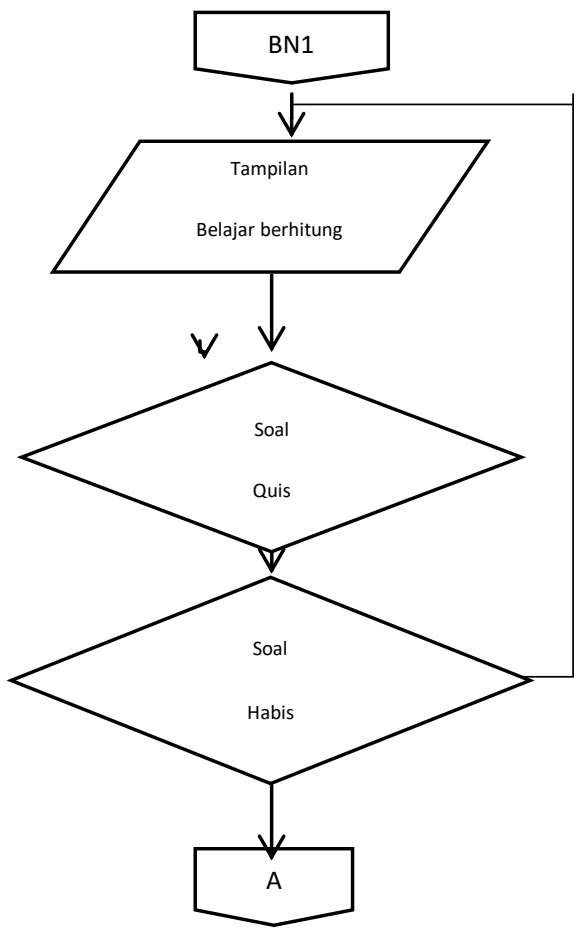

Gambar 7. Flowchart Belajar Berhitung

\section{SIMPULAN}

a. Sistem aplikasi pembelajaran ini adalah media pembelajaran belajar berhitung yang ditujukan untuk Taman kanakKanak di Jagakarsa.

b. Media pembelajaran Berhitung ini dibuat dan didesain berjalan pada smartphone berbasis Android, sehingga menjadi fleksibel dan efektif.

c. Penyampaian materi dalam aplikasi Belajar berhitung sangat mudah dipelajari, karena memadukan visual dan audio, sehingga materi mudah dicerna oleh anak, dan meningkatkan ketertarikan anak dalam belajar.

\section{UCAPAN TERIMAKASIH}

Terima kasih kepada Kemenristek Dikti, LPPM Universitas Indraprasta PGRI dan pihak Taman Kanak-Kanak Kecamatan Jagakarsa dalam dukungan baik secara material maupun spiritual sehingga penelitian ini dapat terlaksana.

\section{DAFTAR PUSTAKA}

[1] Syaodih, E. Psikologi Perkembangan. Bandung : Mandar Maju. 2013.

[2] Azhar Arsyad. Media Pembelajaran. Bandung: PT Raja Grafindo Persada. 2013.

[3] Sugiyono. Metode Penelitian Kombinasi (Mixed Methods). Bandung : Alfabeta. 2016.

[4] Geagne,R.M. The Condition of Learning 3 Edition.New York: Holt Rinehart and Winston Inc.

Artikel. 2012.

[5] Ghea Putri Fatma Dewi Universitas Negeri Yogyakarta pada tahun 2012 dengan penelitian skripsi berjudul : "Pengembangan Game Edukasi Pengenalan Nama Hewa Dalam Bahasa Inggris Sebagai Media Pembelajaran Siswa SD Berbasis Macromedia Flash". 